\title{
Neutrality, nature, and intergenerational justice
}

\section{Britta Clark}

To cite this article: Britta Clark (2020): Neutrality, nature, and intergenerational justice, Environmental Politics, DOI: 10.1080/09644016.2020.1779564

To link to this article: https://doi.org/10.1080/09644016.2020.1779564

$$
\text { 册 Published online: 16 Jun } 2020 .
$$

\section{Submit your article to this journal $匚$ C}

\section{Џll Article views: 16}

Q View related articles $\llbracket$

View Crossmark data $\nearrow$ 


\title{
Neutrality, nature, and intergenerational justice
}

\author{
Britta Clark \\ Department of Philosophy, Harvard University, Cambridge, MA, USA
}

\begin{abstract}
Suppose the present generation leaves future ones with a world depleted of all the natural resources required for many valuable human pursuits. Has the present generation acted unjustly? According to contemporary theories of liberal egalitarian intragenerational and intergenerational justice, the answer, it appears, is no. The explanation for this verdict lies in the liberal commitment to remaining neutral between different ways of life: many value-laden environmental sites and species are not an all-purpose means to any reasonable human end and so their existence is not directly relevant in an assessment of whether justice obtains. Against this view, I argue that a commitment to neutrality and its underlying justification - the idea that individuals should be equipped to live lives of their own design - in fact supports the opposite conclusion. If justice requires that citizens can pursue whatever way of life they do or might value, then it will also demand the continued existence of the natural resources necessary for those pursuits.
\end{abstract}

KEYWORDS Intergenerational justice; neutrality; John Rawls; future generations; environmental justice

\section{Introduction}

Donald Trump has enacted more sweeping rollbacks of environmental regulation than any president in history. To take a few examples, in 2017 Trump signed bills to reduce the size of Bears Ears National Monument by $85 \%$ and the Grand-Staircase Escalante National Monument by $51 \%$ (Nordhaus 2018a). In that same year, he withdrew a rule requiring the maintenance of natural resources affected by federal projects and opened the Arctic National Wildlife Refuge to oil and natural gas development (Popovich et al. 2019). Put only somewhat apocalyptically, Trump's environmental agenda might just leave future people a barren and desolate world void of many of the natural places and species we value now.

It is obvious to many that there is something deplorable about bequeathing this kind of earth to our children. Former President Obama, for instance, has lamented that 'rising temperatures could mean no more glaciers in Glacier National Park, no more Joshua trees in Joshua Tree National 
Park ... that's not the America I want to pass on to the next generation' (Obama 2016). And philosophers often seem to agree. Brian Barry has declared that though future people 'might learn to find satisfaction in totally artificial landscapes, walking on the astroturf amid the plastic trees while the electronic birds sing overhead ... we cannot but believe that something horrible would have happened to human beings if they did not miss real grass, trees, and birds' (Barry 1997, p. 50). Call the world Barry imagines - an earth depleted of what we now call 'nature' ${ }^{\text {' }}$ the 'Horrible World'. But what, exactly, is so horrible about it?

This is a big question, and below I will explore one aspect of it. I want to know whether dominant theories of liberal equality register the Horrible World as unjust. For today, I set aside the thought that the Horrible World is aesthetically bad or that the places destroyed were intrinsically valuable. ${ }^{2}$ To make some progress on this still ambitious inquiry, I proceed in three main sections. In the next section, I examine prominent theories of liberal justice between contemporaries, in particular the work of John Rawls. I argue that the liberal commitment to remaining neutral between conceptions of the good makes these theories unable to diagnose any injustice in the Horrible World. In the subsequent section, I turn to less well trodden territory and argue that Rawls' view of intergenerational justice, as well as a recent proposal drawing on his work, likewise fail to reflect the Horrible World complaint.

What, then, are we to make of any lingering suspicion that it is unjust to leave future people the Horrible World? In the final section I argue that neutrality does not in fact warrant the exclusion of natural resources from what future people are owed. In fact, the motivating thought behind neutrality - that individuals should be equipped to lead lives of their own design - supports the claim that the present generation is obligated to preserve natural resources when those resources are required for the very possibility of a particular pursuit. And, though my argument is first presented in terms of intergenerational justice, it turns out that the preservation of such spaces is also owed to presently coexisting people. I conclude, however, by suggesting some reasons why, when it comes to long-term environmental damage, the distinction between intra and intergenerational justice remains salient.

To start, let me explain three features of the Horrible World that will shape my discussion:

- In the Horrible World, the environmental goods required for many of the projects and ways of life of presently living people no longer exist. I will assume for now that the existence of such environmental goods is indeed necessary for many valuable human pursuits: from recreational pastimes to indigenous spiritual practices to the particular ways of life of small island nations, many undertakings undeniably rely on the existence of lakes, beaches, rivers, and 
plant and animal species. I am concerned below with both token features of the natural world - Bears Ears National Monument - and more general aspects of the environment such as 'rivers.' Following recent sustainability literature, I will often call these environmental goods Sociocultural Natural Capital, or SCNC. ${ }^{3}$

- In the Horrible World, humans have developed technology that allows them to satisfy, without the use of SCNC, all their basic biological needs.

- In the Horrible World, citizens live under otherwise just institutions and have an adequate set of life options to choose from. You might imagine, for instance, that environmental destruction has made other opportunities and ways of life possible.

Noting these three qualities of the Horrible World helps make my central question more precise. I am not asking whether future people have been treated unjustly if they are left an environment that provides them with meager life opportunities, or one so depleted that it would make sense to say that their rights have been violated. ${ }^{4}$ Rather, I want to know whether there is anything unjust about revoking from future people the option for them to participate in currently valuable human pursuits involving the natural world. ${ }^{5}$

\section{SCNC and intragenerational justice}

I have cast this question and much of my forthcoming discussion in terms of intergenerational justice, which I am understanding here as justice between individuals that never coexist. And though we are often enjoined to preserve the environment 'for future generations,' it would be premature, I think, to continue to investigate the role of SCNC in our nascent theorizing of intergenerational justice without first examining more familiar intragenerational proposals. In this section, then, I ask the following: can a standard intragenerational Rawlsian view diagnose any injustice in the Horrible World? I will argue, with others who have come before me, that the answer is no. ${ }^{6}$

To make my case, we'll have to step back and consider where SCNC best fits into

Rawls' theory. Rawls himself does not substantively address this. A natural place to look, though, is in Rawls' answer to what has come to be known as the question of the 'metric' of justice. This metric is a description of the features of a representative individual's situation that are to be assessed to determine whether persons like them have been treated justly. In other words, what, exactly, should we measure to compare different people's circumstances? 
Rawls' answer to the metric question is influenced by his commitment to allowing individuals to form, revise, and pursue their conception of the good without external influence. This means that the relevant measure of distributive shares cannot be based on the satisfaction of an individual's informed preferences or whether they have at their disposal the goods required for the most important human projects. For Rawls, determining if a person has been treated justly does not depend on whether they have what they actually want or even what they should want. Instead, justice requires that each individual have the resources to autonomously design their life, forming an everrevisable view about what they want and pursuing whatever that happens to be on equal terms with others.

This thought leads Rawls and other liberals to adopt a 'neutral' or 'nonperfectionist' answer to the metric question. To avoid privileging certain conceptions of the good, thereby constraining some individuals' ability to pursue whatever projects they deem valuable, the measure of distributive shares must be some set of resources that are useful towards any justicerespecting pursuit. With this in mind, Rawls looks to specify a set of neutral primary goods that 'normally have use whatever a person's rational plan in life' (Rawls 1971, p. 62). 'Income and wealth,' and 'the social bases of selfrespect,' for instance, are paradigmatically neutral primary goods. If instead the metric of justice was some non-universally valuable good - basketballs, let's say - we would be treating those that do not value basketball as having less of a claim to live a life of their own design. Importantly, though, Rawls does not aspire for the fair distribution of primary goods to have neutral consequences with regard to which ways of life fare best in a society (Rawls 1988, p. 260). Rather, the central thought is this: the metric of justice should be framed not in terms of the final goods that people value, but in terms of the principal means to pursue whatever it is that they do or might value.

With this sketch of Rawls' view in hand, it is clear that the neutrality constraint excludes SCNC from the metric of justice. Despite some environmentalists' intuitions to the contrary, rivers, lakes, and species are not the kinds of things that everyone has reason to want whatever else they want; SCNC is not an all-purpose means to the realization of one's plan in life. In fact, many important projects may be best pursued by developing and despoiling such resources. On Rawls' articulation of the metric of justice, though a just distribution of primary goods will make environmental pursuits possible, we need not examine SCNC itself to determine if justice obtains. Rawls affirms this conclusion, noting that 'the status of the natural world and our proper relation to it is not a constitutional essential or a basic question of justice' (Rawls 1971, p. 246).

This approach to SCNC is shared by other liberals. Ronald Dworkin, for instance, leaves SCNC outside the metric of justice for similar reasons of neutrality. He describes a potential dispute between developers looking to 
construct a 'useful dam' and an environmental group advocating for the preservation of a species of snail darter, ultimately concluding that the debate is a matter of equally valid albeit conflicting preferences (Dworkin 1981, p. 202; cf. Miller 1999, p. 160). The debate should be resolved via some democratic mechanism, but whether the snail darter continues to exist is not itself a concern of justice.

For these prominent theorists, it looks like including SCNC in the metric of justice would illegitimately import a specific conception of the good into a neutral space, equivalent to claiming that each is owed, as a matter of justice, a share of basketballs. I am sympathetic to this impulse: I do not wish for my argument to turn on the idea that the existence of SCNC is the kind of thing that individuals want regardless of what else they want, or the perfectionist claim that pursuits involving nature are superior. Indeed, even if this latter claim were true it would not entail that SCNC ought to be included in the metric of justice. Again, it is a crucial feature of the liberal view that what is most important is not that people take up activities conducive to flourishing, but that they are provided the resources to lead lives 'from the inside' (Kymlicka 2002, p. 216).

What should be clear at this point is that on familiar liberal views, environmental protection is downstream from justice. As Rawls emphasizes, decisions regarding the preservation of SCNC are to be governed by 'the benefit principle and not the principles of justice' (1971, p. 250). But this might not be cause for concern: many theorists seem optimistic that a fair distribution of some all-purpose metric will enable citizens to effectively prevent something like the Horrible World. Perhaps, even, though SCNC is not itself a matter of justice, neutral state support can promote environmental preservation. Dworkin, for instance, notes that institutional incentives may be necessary in order to maintain establishments such as National Parks (Dworkin 1985, ch., p. 11), and Rawls similarly suggests that SCNC is a public good potentially warranting state funding (1971, p. 250). Of course, these provisions remain decidedly neutral - the liberal state cannot impose the protection of SCNC, and decisions regarding environmental preservation should be voted on 'unanimously, or at least approximately so,' (Rawls 1971, p. 250). ${ }^{7}$ Rawls and Dworkin do not discuss natural resources in much more depth elsewhere, and seem confident that the sort of neutral state support outlined above will be enough to preclude the Horrible World.

I think this is unduly optimistic. To see this, consider a reasonably just society with a 100 -acre forest, a forest that is required for many other important pursuits. What claims do present day people have with respect to this resource on the liberal view just outlined? Few are in support of the thought - pejoratively termed 'absurdly strong sustainability' ${ }^{8}$ - that justice requires the forest to remain unchanged over time. Not every instance of environmental modification can plausibly be considered an injustice against 
those for whom the resource is valuable. What the forest-valuers are owed on the Rawlsian account is the basic liberties ensuring that their preferences are registered in decisions regarding the forest and a fair share of primary goods to pursue a life involving it if they so choose.

The just society, then, will permit some development and degradation of the forest. Even if the state offers neutral tax incentives for cultural institutions, there is no guarantee that citizens will choose to support environmental protection in light of other options, nor does it seem plausible that they will make large enough contributions to prevent every instance of environmental damage. Suppose, then, that in a super-majority or even unanimous vote like the one imagined by Rawls, the community agrees to cut down an acre of the forest for a basketball factory. The forest is now 99 acres. The next year, citizens vote to install a museum. The forest is now 98 acres. And so on. Eventually, the forest is 50 acres. We have yet to see an instance of injustice.

But here is the problem: putatively just environmental modification is strikingly unidirectional. While each instance of benign damage is unlikely to be reversed, every instance of environmental preservation, conservation, or improvement remains subject to contestation. Once the forest is 50 acres, it will likely not return to its former size. It's hard to see the basketball factory, a source of employment and income, being torn down to return the land to forest. In contrast, the forest-valuers who work to preserve it are always vulnerable to the demands of the basketball-valuers, the museum-valuers, and so on. As Elizabeth Ellis (2016) puts the problem, when it comes to environmental damage, 'each win for the development side is permanent, while each win for the conservation side is temporary' (507). In short, the idea here - one commonly evoked in environmental policy and sustainability discussions - is that many environmental damages are irreversible, at least over the timespan of a human life. ${ }^{9}$

The proposition that some environmental damages are irreversible will be important in what follows. And though I cannot offer a full defense of this contested claim here, let me outline two points in support. First, some instances of environmental modification are, at least at present, technologically irreversible. Species extinction, the sea level rise that threatens historic beaches, soil erosion and desertification, ocean acidification, and the death of coral reefs are just the beginning of a lengthy list of changes that are unlikely to be reversible. Second, psychological factors contribute to the irreversibility of environmental decline. As individuals determine whether they are willing to pay for the preservation of SCNC, they will take as a baseline the conditions they have themselves encountered (Horowitz 2002, p. 252). In our forest example, for instance, those that only experience the forest at the diminished dimension of 50 acres will take 50 acres as their standard for environmental quality, and further as loss-averse creatures they will be far 
more concerned with preventing additional losses to the size of the forest than they will be with a comparable improvement or return to past conditions (Kahneman and Tversky 1979). Moreover, even with increased deforestation they will adapt to changing conditions and be unlikely to notice a decline in wellbeing (Raudsepp-Hearne et al. 2010).

It seems plausible then, that these technological and psychological factors render some damages to SCNC irreversible. You would, of course, be right to notice that the claim of irreversibility seems to depend on a further claim of irreplaceability or incommensurability (Sunstein 2008, p. 15-17). That is, what makes irreversible damage to SCNC meaningfully irreversible is the fact that that SCNC has no substitutes. Though substitutability has generated extensive discussion, we can set much of it aside here: the debate tends to turn on whether human-made substitutes can generate the same amount of wellbeing as natural capital like SCNC. All that matters for my purposes, though, is that SCNC is a non-substitutable requirement for the very possibility of particular human pursuits. Though I will return to this thought, I will continue to assume for now that this is true. Some ways of life are impossible without the existence of particular resources; this is true regardless of the amount of wellbeing provided by any alternative.

What I hope to have established above is that a basic Rawlsian picture can neither directly include SCNC in the metric of justice nor preclude the Horrible World with additional institutional projections. Further, note that the generation that inherits that Horrible World will not have a legitimate claim to live in a world like ours. Though they are born into depleted circumstances, they can still have all their basic liberties protected, and primary goods can still be justly distributed. And nowhere does Rawls or Dworkin state, nor does it seem plausible, that persons have a claim to be able to pursue any imaginable human project. The future people in the Horrible World on the views just explored have no more of a claim to be able to live lives as snail darter enthusiasts or birders than we presently have a claim to live our lives as Samurai Warriors. ${ }^{10}$

Thus far, though, I've focused on justice between coexisting people. Given the long-term nature of environmental harms, it makes sense that this might not be the right place to look. Intuitively, if there is an injustice in the Horrible World, it is not between the individuals that inherit it, but between currently living people and our Horrible World descendants. Accordingly, I now turn to the less frequented conceptual territory of intergenerational justice.

\section{SCNC and intergenerational justice}

Do liberal theories of intergenerational justice provide additional conceptual resources that might impugn the Horrible World? It's not entirely clear. 
Rawls spent only a few pages discussing justice between non-contemporaries, and in general theories of intergenerational justice are less developed than their intragenerational counterparts. In this section I will argue that a plausible reading of Rawls' intergenerational theory of just savings does not register the Horrible World as an injustice. Nor can more thorough proposals that - in the spirit of Rawls - conceive of intergenerational justice in terms of the all-purpose resource of 'ecological space.'

Take note at the outset that I will be assuming that it is possible to stand in relations of justice with future people. Admittedly this assumption may be premature: attempts to defend our obligations to future people run into significant difficulties. ${ }^{11}$ But I take for granted that there is some currency of advantage that we can use to diagnose - by comparing the life prospects of people that never coexist - cases of distinctively intergenerational injustice.

What, then, is the appropriate intergenerational metric? On Rawls' view, intergenerational justice does not require that non-overlapping individuals holds a particular share of primary goods relative to each other; he rejects an intergenerational difference principle that would allow only those intergenerational inequalities in primary goods that would benefit those in the worst-off generation (Rawls 1971, p. 255-58, Wall 2003, p. 79). Rather, once just intragenerational institutions are set up, our intergenerational duties are exhausted by the requirement to save sufficient material capital such that future people can maintain those just institutions - the so-called just savings principle (Rawls 1971, p. 284-88). ${ }^{12}$

Just savings is not particularly demanding. Intergenerational injustice only obtains if those in an earlier generation act such that later generations are no longer able to protect the basic liberties of its citizens, or if the economic institutions that regulate unjustifiable inequalities no longer function. Once more, it's hard to see how this sketch of Rawls' intergenerational metric has the conceptual resources to mark any injustice in the Horrible World. Recall that though the Horrible World is horrible by the standards of some of today's citizens, the Horrible World still has well-functioning and intragenerationally just - by Rawls' standards - institutions. The citizens of the Horrible World can still pursue whatever versions of the good life have been made available via the destruction of the natural world.

Though Rawls himself did not articulate a comprehensive theory of intergenerational justice, some theorists have proposed Rawlsian-inspired views that look to capture the intergenerational character of environmental concerns. Steve Vanderheiden (2009) and Tim Hayward (2006), for instance, rightly observe that, unlike Rawlsian primary goods, many natural resources are finite - or at least there is a finite amount that we can consume without disastrous consequences. Vanderheiden and Hayward call these zero-sum resources 'ecological space,' which they define loosely as 'the amount of biologically productive land and water area required to produce the 
resources consumed and to assimilate the wastes generated using prevailing technology' (Hayward 2006, p. 359). The central thought is that intergenerational justice should register the fact that one generation's use of ecological space entails the decline of another's. Roughly, they propose that 'each human being should be allocated a share of ecological space' (Page 2007, p. 460), and that the project of intergenerational justice is incomplete without a principle for the intertemporal distribution of uniquely finite natural resources.

The idea that ecological space is at least part of the evaluative standard of intergenerational justice shares the liberal commitment to neutrality. Ecological space is taken as a universally valuable resource the fair distribution of which will secure even future people's capacity to autonomously form and revise their conception of the good. As Vanderheiden puts it, the 'allocation of ecological space defines the sphere in which persons can make the kind of autonomous choices that liberalism celebrates, within the constraints that it recognizes' (259). However, despite the important recognition of zero-sum resources, ecological space does not capture any injustice in the Horrible World. Conceiving of environmental goods under the single heading of 'ecological space' obscures distinctions between the different roles played by such goods, failing to provide theoretical support for the thought that intergenerational justice might require that some specific resources SCNC - should not be distributed for consumption. Moreover, the concern of theorists of ecological space is centered upon the role of such resources in the provision of basic needs - needs which are provided for in the Horrible World. Though there is more to explore here, the crucial point is this: one generation might use up only its fair share of 'ecological' space, while still destroying SCNC. Justice of ecological space is consistent with the Horrible World.

So it looks like these two metrics of intergenerational justice do not diagnose the Horrible World as unjust. Where are we to go from here? A first option is to say that the Horrible World intuition is mistaken; the liberal environmentalist must admit that environmental preservation is not a matter of justice. A second option is to argue the SCNC should be included in our theories of intragenerational justice, a route taken up by many green political theorists and philosophers. ${ }^{13}$ However, these theorists tend not to finely distinguish between SCNC in its role supporting the possibility of certain human projects, and aspects of the environment - clean air and water, a habitable climate - which are more plausibly seen as all-purpose means to one's ends (e.g., Caney 2010). On this approach, if SCNC is preserved, it seems like a happy consequence of a plausible obligation to maintain other more basic environmental services. Where a distinction is indeed drawn, decisions regarding non-universally valuable environmental goods are left to democratic mechanisms or deliberative procedures that 
register only existing people's preferences (e.g. Miller 1999). Even Marcel Wissenburg, who argues that 'no goods shall be destroyed unless unavoidable and unless they are replaced by perfectly identical goods' (1999, p. 123) leaves a determination of what counts as 'unavoidable' to be a matter of existing individual tastes, and explicitly accepts that a 'global Manhattan without the park,' in which all SCNC is destroyed, does not necessarily constitute an injustice. Further, though some, including Brian Barry (1997) maintain that future people should be left with a set of 'adequate options' from which to design their lives, it is often conceded that it is difficult to offer a principled distinction between the options available in the Horrible World and the options we enjoy today. In sum, the claim that there is some injustice in bequeathing the Horrible World to our successors has not yet enjoyed a reasoned defense.

\section{Neutrality and SCNC}

In this final section, I try to make some progress by approaching the Horrible World intuition from the perspective of intergenerational justice. To do this, I will first defend an idea I've thus far assumed: certain human projects can be made impossible to pursue if the resources required for those projects are irreversibly destroyed. If this is right, then a commitment to remaining neutral between different conceptions of the good no longer justifies the exclusion of such resources from the metric of intergenerational justice. In fact, the neutralist should endorse the opposite conclusion. If the present generation is obligated to ensure that it is possible for future people to pursue any reasonable conception of the good, then the present generation is also obligated to ensure the continued existence of the resources required for such conceptions. However, though my proposal is most vivid in its intergenerational form, it turns out that the same argument applies to the intragenerational case as well. Does this mean that the distinction is trivial? I will close this section by suggesting some reasons to think that it is not.

First, let me review and make more precise exactly the challenge posed to liberals hoping to argue that bequeathing the Horrible World is an intergenerational injustice. We observed above that Rawlsian just savings and ecological space both excluded from the purview of justice resources that are not an all-purpose means to human ends and as a result could not diagnose any injustice in the Horrible World. Theorists seemed optimistic that a fair provision of neutral primary goods will prevent much objectionable irreversible environmental damage: citizens will be able to register their preferences for a world with SCNC, and if needed neutral state support can incentivize conservation alongside other public goods. This optimism was perhaps appropriate in earlier times when humankind's influence was not drastic 
enough to occasion irreversible environmental damage, but today, I argued, it is unfounded.

Yet, an optimism that valuable opportunities will persist is also an important feature of the liberal view. Liberals celebrate that in the free marketplace of ideas facilitated by the basic liberties, some ways of life will be replaced with more valuable projects and activities. As Mill puts it, 'the worth of different modes of life should be proved practically' (Mill 1982, p. 53). The human pursuits that are feasible in a given historical moment are always and should always be in flux, lest people be confined to existing practices in objectionable ways. Conceptions of the good that are most popular in a society should evolve, and as noted a commitment to allowing individuals to lead lives of their own design does not require that each of the innumerable possible human pursuits is always a popular or practical option.

So if leaving the Horrible World is an injustice, it cannot be because those that live in it have been denied a maximally expansive set of options from which to choose. Of course, liberals can't make the perfectionist claim that citizens in the Horrible World are owed SCNC on the basis of the objective superiority of SCNC-involving pursuits, nor, as I've emphasized, is it plausible that $\mathrm{SCNC}$ is an all-purpose means to whatever one's ends happen to be. Is there any other principled reason to include SCNC in the metric of intergenerational justice? The challenge can be put like this: without recourse to the above arguments, do we have any reason to distinguish between the fact that today it's not feasible to be a Samurai Warrior and in the Horrible World one cannot pursue projects involving SCNC?

We have already seen a potential basis for making this distinction. Dworkin gives us a hint. The liberal, he says, is free to claim that 'the conquest of unspoiled terrain by the consumer economy is self-fueling and irreversible, and that this process will make a way of life that has been desired and found satisfying in the past unavailable to future generations ... this way of life will become unknown, so that the process is not neutral amongst competing ideas of the good life, but in fact destructive to the very possibility of some of these.' (Dworkin 1985, p. 202). Here, then, is the response to the challenge that I will explore: some human projects can be made impossible to pursue, and others can only be made less feasible. This is because some - but not all - pursuits necessitate the existence of certain physical features of the world. Thus far, I've assumed something like this last claim to be true. I will now clarify and defend this assumption.

First, notice that some pursuits are by their very nature concerned with engaging with token places that were of value to one's ancestors and will likely be of value to one's progeny (Thompson 2009, Scheffler 2013). Existing members of the Zuni tribe, descendants of the inhabitants of the shrunken Bears Ears National Monument, wish to pursue ways of life that involve not simply canyons and mesas generally, but their particular ancestral homeland 
(Nordhaus 2018b). If those token places are irreversibly destroyed, then conceptions of the good that are centered around those specific sites become impossible to pursue. It's hard to imagine what it would look like to engage with one's ancestral home if one's ancestral home has been developed into an oil field.

The second and more difficult claim to establish is that some pursuits that do not require such intergenerationally valuable token resources can likewise become impossible to pursue in the absence of certain SCNC. But this is plausible: in the Horrible World a litany of recreational, spiritual, and otherwise valuable human undertakings - birding, fishing, swimming, climbing, gardening - do not seem possible to pursue despite the fact that these projects are not concerned with specific token sites. Notice an important difference between making a pursuit impossible and making a pursuit less feasible or impractical. Though we find an individual who pursues life as a Samurai warrior odd, in a place like the Horrible World the pursuit of projects involving the natural world will be irrational-comparable to a contemporary individual whose conception of the good involves living with dinosaurs (Ott 2004, p. 144). The Samurai-fighting enthusiast will likely have little success, yet she can meaningfully pursue her admittedly strange idea of a good life. The resources required for Samurai-fighting cannot be irreversibly removed from existence, for there are many ways to construct the required swords and shields. The present generation cannot altogether preclude future individuals from pursuing that particular way of life. In contrast, when it comes to SCNC, this does not seem to be the case: it is simply not possible for the citizens of the Horrible World to pursue any activities involving the natural world with any chance of success.

At this point you're likely worried that this last claim is too strong. It's not really impossible, you might object, to pursue birding in the absence of real birds; you might devote your life to de-extinction technologies or perhaps virtual birds will do the trick. Looking ahead, you might rightly be concerned that my view will end up being overdemanding: surely it is not a concern of justice if wealthy future people cannot ski in the Alps or raft down a pristine river. This is an important objection, and it sheds light on a larger question that I cannot address in full here. To know whether my view has these sorts of demanding implications, we need to know what counts as a 'pursuit,' 'way of life,' or 'conception of the good.' Further, we need an account of when natural resources are indeed necessary for the very possibility of pursuing a way of life. Though I will not investigate these questions here, I suspect that any plausible account will include both intergenerationally valuable token resources as well as some other general types of SCNC.

Regardless of how one answers the above questions, I believe I have identified the right kind of distinction between conceptions of the good that require the existence of SCNC and those that do not. The former is 
distinctive not because such projects are superior or because those resources are all-purpose means to one's ends, but because projects requiring SCNC can be made not just impractical but impossible to pursue.

The final step is to argue that this distinction can be wielded to show that the Horrible World is an injustice. Recall the motivation supporting liberal neutrality. A neutral metric of justice was important because it embodied the idea that justice should not privilege particular ways of life, but rather ensure that individuals can form a revisable conception of what they value as well as pursue whatever that ends up being.

But we also saw above that the intergenerational metrics of just savings and ecological space were consistent with allowing some conceptions of the good to become not just impractical, but impossible. That is, these purportedly neutral metrics of justice did exactly what they were designed to avoid: they dictated in advance the kinds of lives that future humans can possibly lead. Though individuals in the Horrible World can form and revise their values against a background of ample options, some options will be simply unavailable to them. And they won't be unavailable in the sense that other undertakings have become more popular. Rather, they are impossible because the resources necessary for those pursuits no longer exist.

Put otherwise, the threat to many conceptions of the good is only that humans may cease to value them, and they will become unpopular ways of life. But the threat to conceptions of the good requiring SCNC is distinctive: the resources required for these projects can be irreversibly destroyed, making these projects impossible to pursue. To be sure, many human undertakings will still fade out of fashion, becoming less feasible or desirable for future people. And for the most part this evolution is the product of humans reflecting on and deciding what is valuable, and teaching their children the same. Those children can form and revise their conceptions of the good in spite of this education, choosing if they wish to return to a way of life that was valued in the past, attempting to convince others to join them. In general the resources needed to do this are available to them. But in some cases, those resources can be irreversibly destroyed, rendering those projects not just impractical or unpopular, but impossible.

My conclusion, then, is that a commitment to neutrality does not warrant the exclusion of SCNC from the metric of intergenerational justice. This is the deep truth behind Dworkin's point: we ought not make particular ways of life permanently unavailable if we are genuinely committed to ensuring that future individuals can lead lives of their own design. An intergenerational metric that excludes SCNC prescribes, in a manner in deep tension with liberalism's commitment to neutrality, the very sorts of lives that future citizens may be able to pursue. The supposed commitment to neutrality in existing theories of intergenerational justice is anything but, for it allows that the only lives future people can live are those that are still possible once we 
have lived ours. When individuals in a future generation wonder whether they have been treated justly by us, I propose that part of the standard of assessment is that we have not made particular ways of life impossible for them to pursue.

The fact that I have left fairly open what it means to make a conception of the good impossible to pursue means that my argument does not necessarily endorse as demanding of conservation policies as you might have thought. If ways of life are understood as wide and non-descript - like 'being outside' then it will be virtually impossible for the present generation to fail in an obligation to keep this way of life around. In contrast, if ways of life are narrowly specified - 'skiing on real snow at X resort' - our present obligation to maintain the possibility of all such options would impose unreasonable demands. I suspect that the right view falls somewhere between these two extremes.

At this point, though, it appears the distinction I have been making between intra and intergenerational justice is not doing all that much work, for the very same reasons that supporting the inclusion of SCNC in the metric of intergenerational justice supports the inclusion of SCNC in what is owed to existing people. If the Horrible World were to come to exist tomorrow, with pursuits involving snail darters, forests, and the like replaced by technological substitutes, existing people would find some ways of life impossible. This restriction, like the intergenerational case, is inconsistent with the liberal commitment to providing to each the required resources to go about pursuing whatever it is they happen to value. Those who already hold or come to form a conception of the good requiring the destroyed resources will find their conception of the good not only unpopular, but impossible, as will future people that might one day wish to pursue projects involving SCNC.

However, I think we should keep the intra/intergenerational distinction in clear view. If I am right to think that acting justly towards future people requires not irreversibly restricting their ability to meaningfully pursue conceptions of the good, then the present generation has environmental obligations not easily identified solely in terms of what is owed to present people.

First, in what has been called the problem of delayed harms, the present generation might act in ways that occasion irreversible damage to SCNC that will only be felt in the future. Currently living people, that is, could continue to pursue valuable projects over the course of their lifetime while at the same time setting in motion processes that will make these same projects impossible in the future. Climate change and extinction are particularly obvious examples of this: we are presently acting in ways that may not make some conceptions of the good impossible for ourselves, but will render those same projects impossible for our successors. Think, for instance, of a future 
individual who forms a conception of the good involving living on the same Fijian island as their ancestors - an island that will soon be underwater due to anthropocentric climate change.

The second reason that the distinction between intergenerational and intragenerational justice remains salient in the case of irreversible environmental damage relates to the kind of unanimous decision-making mentioned by Rawls. You might think that when it comes to the goods required for particular projects, an existing generation is within its rights to make that good unavailable for themselves. Acknowledging that not all human projects can be pursued at the same time, the present generation could unanimously vote to make some conceptions of the good impossible in order to more effectively pursue other valuable activities. For instance, we might unanimously agree to stop funding space exploration in favor of building a new basketball court in every county in America. Similarly, you might think that the present generation could permissibly develop public lands through a unanimous vote. But, if the status of SCNC in the metric of a distinctively intergenerational account of justice is kept in mind, this latter option impermissible. While our successors could reverse the decision to focus on the sporting life instead of life on Mars, future generations cannot choose to continue to pursue those ways of life that have been rendered impossible by the imagined development. In short, recognizing that an obligation to ensure that no conception of the good becomes impossible to pursue is an obligation owed to everyone who will ever live and places more stringent demands and constraints on present action than an exclusive focus on obligations to presently existing people.

\section{Conclusion}

The practical upshot of all this is that environmental preservation and conservation can be justified in terms of the familiar obligation to enable all citizens to pursue whatever it is they do or might value. Though the liberal cannot, on neutral grounds, say that these ways of life are more valuable than the opportunities that might replace them, we can say, on neutral grounds, that no project should be made impossible to pursue. Though I do not fill in an account of when exactly a way of life is impossible, I have suggested there are indeed some conceptions of the good that cannot be pursued in the absence of physical features of the world - SCNC. If this is right, then it appears Rawls was wrong to say that 'there is no more justification for using the state apparatus to compel some citizens to pay for unwanted benefits that others desire than there is to force them to reimburse others for their private expenses' (1971, p. 250). In fact, the justification is that, without stricter environmental protection, ways of life that have previously been possible will become meaningless and unintelligible pursuits. 
The even broader lesson here, I think, is that our our theorizing about intergenerational justice cannot avoid saying something about what sorts of lives future citizens should have the option to lead. It is an inevitable and benign fact about the development of human societies that the preferences and goals of any generation are deeply influenced by what the past generation themselves valued and what sort of natural and built reality was sustained for them. Yet, we have an increasing ability to constrain, in unprecedented ways, the sorts of projects our progeny can pursue. If we are to stay true to a commitment to enabling humans to freely and autonomously pursue whatever kind of life they find valuable, we must seriously consider our increasing capacity to determine what ways of life remain possible.

\section{Notes}

1. I will remain neutral with regard to the question of what the term 'nature' should refer to. For my purposes, the colloquial thought that nature is all those physical features of the earth that are not of primarily human creation should suffice, but see Chapter 2 in Sakar (2012) for a summary of competing views.

2. Many have argued that there are justice-independent reasons to preserve environmental goods because, for instance, they are intrinsically valuable. See Scanlon (1998, p. 183) for a specific example or Brennan and Lo (2016) for a full survey.

3. See Chiesura and Rudolf (2003), and Satz et al. (2013) for examples.

4. See Brandstedt and Bergman (2013) for a thorough treatment of the rightsbased approach to climate change.

5. My analysis could well be extended to other objects that are indispensable for presently living people's projects: works of art, temples, or churches, for instance. Here, I focus on natural objects, but see Young (1989) for a somewhat similar discussion involving works of art.

6. For some who have come to the roughly similar conclusion that Rawlsians cannot easily accommodate environmental concerns, see Sagoff (2007) Miller and Wissenburg's contributions in Dobson (1999), and Gardiner (2011).

7. See Brighouse (1995) for an argument that neutrality makes it even more difficult than Dworkin might have thought to justify even neutral state support for cultural projects.

8. See Solow (1974).

9. For instance, the famous 'precautionary principle' in the 1992 Rio Declaration demands that 'where there are threats of serious or irreversible damage, lack of full scientific certainty shall not be used as a reason for postponing costeffective measures to prevent environmental degradation'.

10. Thanks to an anonymous reviewer for highlighting this example; it plays a central role in what follows.

11. For instance, I will not address the non-identity problem here. See Gosseries (2008) and Meyer (2016) for summaries of the various conceptual challenges posed by intergenerational relations. 
12. In fact, for Rawls intergenerational justice is a two-stage sequence. Before just institutions are set up, present individuals have an obligation to save to create them (1971, p. 255-258). I will focus on the second stage.

13. For a sampling, see the essays in Dobson (1999).

\section{Acknowledgments}

Many thanks to Elizabeth Ellis, Michael Lebuffe, Jacinta Ruru, and others at the University of Otago for their comments on the initial versions of this manuscript. I am indebted to the United States Fulbright Graduate Student Program for their generous support of a year of research in New Zealand, an experience that inspired this project. Later drafts benefited immensely from the incisive feedback of Lucas Stanczyk, Emilio Mora, Gina Schouten, and many fellow University of Otago and Harvard University graduate students. Thorough observations from three anonymous referees were also greatly appreciated.

\section{Disclosure statement}

No potential conflict of interest was reported by the author(s).

\section{Funding}

This work was supported by the Fulbright New Zealand.

\section{References}

Barry, B., 1997. Sustainability and intergenerational justice. Theoria, 44 (89), 43-64. doi:10.3167/004058197783593443

Brandstedt, E. and Bergman, A.K., 2013. Climate rights: feasible or not? Environmental Politics, 22(3), 394-409. doi:10.1080/09644016.2013.775723

Brennan, A. and Lo, Y., 2016. Environmental ethics. In: E.N. Zalta, ed. The Stanford Encyclopedia of philosophy. Stanford: The Metaphysics Research Lab.

Brighouse, H., 1995. Neutrality, publicity, and state funding of the arts. Philosophy \& Public Affairs, 35-63. 241 doi:10.1111/j.1088-4963.1995.tb00021.x

Caney, S., 2010. Climate change, human rights, and moral thresholds. In: S.M. Gardiner, ed. Climate ethics: essential readings. Oxford: Oxford University Press, 163-177.

Chiesura, A., and Rudolf D., 2003. Critical natural capital: a socio-cultural perspective. Ecological Economics, 44.2-3, 219-231. doi:10.1016/S0921-8009(02) 00275-6

Dobson, A., 1999. Fairness and futurity: essays on environmental sustainability and social justice. Oxford: Oxford University Press.

Dworkin, R., 1981. What is equality? Part 1: equality of welfare. Philosophy \& Public Affairs, 10, 185-246.

Dworkin, R., 1985. A matter of principle. Oxford: Clarendon Press.

Ellis, E., 2016. Democracy as constraint and possibility for environmental action. In: T. Gabrielson, C. Hall, J.M Meyer, and D. Schlosberg, eds. The Oxford handbook of environmental political theory. Oxford: Oxford University Press, 505-19. 
Gardiner, S.M., 2011. Rawls and climate change: does Rawlsian political philosophy pass the global test? Critical Review of International Social and Political Philosophy, 14 (2), 125-151. doi:10.1080/13698230.2011.529705

Gosseries, A., 2008. Theories of intergenerational justice: a synopsis. S.A.P.I.EN.S. Surveys and Perspectives Integrating Environment and Society, 1 (1), 39-49 doi:10.5194/sapiens-1-39-2008

Hayward, T., 2006. Global justice and the distribution of natural resources. Political Studies, 54 (2), 349-369. doi:10.1111/j.1467-9248.2006.00606.x

Horowitz, J.K., 2002. Preferences in the future. Environmental and Resource Economics, 21(3), 241-258. doi:10.1023/A:1014592629514

Kahneman, D. and Tversky, A., 1979. Prospect theory: an analysis of decision under risk. Econometrica, 47 (2), 263-292. doi:10.2307/1914185

Kymlicka, W., 2002. Contemporary political philosophy: an introduction. Oxford: Oxford University Press.

Meyer, L., 2016. Intergenerational justice. In: E.N. Zalta, ed. The Stanford Encyclopedia of philosophy. Stanford: The Metaphysics Research Lab.

Mill, J.S., 1982. On liberty. Harmondsworth: Penguin.

Miller, D., 1999. Social justice and environmental goods. In: A. Dobson, ed. Fairness and futurity: essays on environmental sustainability and social justice. Oxford: Oxford University Press, 151-172.

Nordhaus, H., 2018a. What Trump's shrinking of national monuments actually means. In: National geographic, February 2nd. https://www.nationalgeographic. com/news/2017/12/trump-shrinks-bearsears-grand-staircase-escalante-nationalmonuments/

Nordhaus, H., 2018b. What the bears ears monument means to a native American. In: National geographic, October 18th. https://www.nationalgeographic.com/environment/2018/10/bears-earsmonument-native-americans-photography/

Obama, B., 2016. Remarks by the president at sentinel bridge. In: National archives and records administration. National Archives and Records Administration.

Ott, K., 2004. Essential components of future ethics. In: R. Döring and M. Rühs, eds. Ökonomische Rationalität und praktische Vernunft, Würzburg. Würzburg: Königshausen \& Neumann, 83-108.

Page, E.A., 2007. Intergenerational justice of what: welfare, resources or capabilities? Environmental Politics, 16 (3), 453-469. doi:10.1080/09644010701251698

Popovich, N., et al., 2019. 83 environmental rules being rolled back under Trump. The New York Times.

Raudsepp-Hearne, C., et al., 2010. Untangling the environmentalist's paradox: why is human well-being increasing as ecosystem services degrade? BioScience, 60 (8), 576-589. doi:10.1525/bio.2010.60.8.4

Rawls, J., 1971. A theory of justice. Cambridge: Harvard University Press.

Rawls, J., 1988. The priority of right and ideas of the good. Philosophy \& Public Affairs, 17, 251-276.

Sagoff, M., 2007. The economy of the earth: philosophy, law, and the environment. Cambridge: Cambridge University Press.

Sarkar, S., 2012. Environmental philosophy: from theory to practice. Hoboken: John Wiley \& Sons.

Satz, D., et al., 2013. The challenges of incorporating cultural ecosystem services into environmental assessment. Ambio, 42 (6), 675-684. doi:10.1007/s13280-013-0386-6

Scanlon, T., 1998. What we owe to each other. Cambridge: Harvard University Press. Scheffler, S., 2013. Death and the Afterlife. New York: Oxford University Press. 
Solow, R.M., 1974. Intergenerational equity and exhaustible resources. The Review of Economic Studies, 41, 29-45. doi:10.2307/2296370

Sunstein, C.R., 2008. Two conceptions of irreversible environmental harm. $U$ of Chicago Law \& Economics, Olin Working Paper, (407), 08-16.

Thompson, J., 2009. Intergenerational justice: rights and responsibilities in an intergenerational polity. New York: Routledge.

Vanderheiden, S., 2009. Allocating ecological space. Journal of Social Philosophy, 40 (2), 257-275. doi:10.1111/j.1467-9833.2009.01450.x

Wall, S., 2003. Just savings and the difference principle. Philosophical Studies, 116 (1), 79-102.

Wissenburg, M., 1999. An extension of the Rawlsian savings principle to liberal theories of justice in general. In: A. Dobson, ed.. Fairness and futurity: essays on environmental sustainability and social justice. Oxford: Oxford University Press, 173-198.

Young, J.O., 1989. Destroying works of art. The Journal of Aesthetics and Art Criticism, 47 (4), 367-373. doi:10.2307/431136 